\title{
Beached birds and physical forcing in the California Current System
}

\author{
Julia K. Parrish ${ }^{1, *}$, Nicholas Bond ${ }^{2}$, Hannah Nevins ${ }^{3}$, Nathan Mantua ${ }^{1,2}$, \\ Robert Loeffel $^{4}$, William T. Peterson ${ }^{5}$, James T. Harvey ${ }^{3}$ \\ ${ }^{1}$ School of Aquatic and Fishery Sciences, Box 355020, University of Washington, Seattle, Washington 98195-5020, USA \\ ${ }^{2}$ Joint Institute for the Study of the Atmosphere and Ocean, University of Washington, Seattle, Washington 98195, USA \\ ${ }^{3}$ Moss Landing Marine Laboratories, 8272 Moss Landing Road, Moss Landing, California 95039, USA \\ ${ }^{4} 9626$ SE Cedar St., South Beach, Oregon 97366, USA \\ ${ }^{5}$ Northwest Fisheries Science Center, NOAA National Marine Fisheries Service, Newport, Oregon 97366, USA
}

\begin{abstract}
Seabirds have often been proposed as environmental indicators. Beached bird data may provide an additional data source and such data is efficacious because it can reliably be collected by volunteers. In addition to anthropogenic factors, such as oil spills, changes in the ocean-atmosphere can affect carcass beaching rate in 3 non-exclusive ways: (1) direct mortality following storms, (2) mortality via bottom-up food web processes, and (3) increase in carcass delivery due to shifts in surface water movement. We used data from 3 volunteer-based beached bird data sets collected within the California Current System (CCS) to (1) examine the level of response to anomalous ocean conditions in 2005 and (2) explore the degree to which long-term beaching patterns could be explained by one or more of our proposed mechanisms. In 2005, anomalous die-offs of Cassin's auklet Ptychorhamphus aleuticus and the rhinoceros auklet Cerorhinca monocerata occurred in the winter in Monterey. By spring, anomalous die-offs of Brandt's cormorant Phalacrocorax pencillatus and the common murre Uria aalge occurred throughout the CCS. Over the longer term, increases in beaching were associated with changes in the timing and intensity of upwelling and, secondarily, with zonal winds aloft - a potential proxy of shifts in pelagic community composition. These results suggest that a bottom-up food web mechanism best explains seabird beaching, at least in the spring. Correlations of local measures of storminess to seabird beaching rates were weak to non-existent. Correlations were much stronger at the California site ( $8 \mathrm{yr}$ ) and weaker to non-existent at the Oregon site ( $26 \mathrm{yr}$ ). Collectively, these data suggest that relationships between ocean physics and beached bird response may be site specific and/or may reflect choices live birds make vis-à-vis non-breeding distribution.
\end{abstract}

KEY WORDS: Upwelling · Seabird · Common murre - Brandt's cormorant · Cassin's auklet . Rhinoceros auklet

Resale or republication not permitted without written consent of the publisher

\section{INTRODUCTION}

Seabirds comprise one of the most numerous and highly visible components of coastal marine environments worldwide. Because of their ubiquity, range of life-history strategies, relative ease of access while at breeding locations, and collective breadth of diet, measures of seabird diet, growth, demography, abundance, and diversity have variously been proposed as indicators of environmental quality (Furness \& Green- wood 1993, Furness \& Camphuysen 1997). Ideally, comprehensive, long-term monitoring programs - both at-sea and on-colony-would return demographic and ecological indicators at time and space scales relevant to the birds as well as the underlying forcing factors inherent in any regional ecosystem. Practically, this is too expensive, with the result that worldwide only a handful of colony sites have long-term monitoring programs, and even fewer long-term at-sea programs exist. 
One potential solution is to involve citizen volunteers in data collection. Beached bird surveys, because they can be built around standardized protocols and independently verifiable data (i.e. carcass identifications), offer such an opportunity. Worldwide, beached bird survey data have been used to provide data on oiling rates (Wiese \& Robertson 2004), to detect changes in bycatch of fisheries (Forney et al. 2001), and to indicate mortality events associated with biotoxins (Scholin et al. 2000). When performed by trained volunteers, beached bird surveys can yield high quality data over a geographic scale not attainable in any other way.

Changes in the rate at which seabirds are beached, aside from human-caused events (e.g. oil spills), are a complex function of bio-physical coupling in the coastal marine environment. At regional scales, the seasonal pattern of upwelling influences the distribution, abundance, and quality of prey (Roemmich \& McGowan 1995, Anderson \& Piatt 1999), and thus of seabird predators both live (Veit et al. 1996) and dead (Granadeiro et al. 1997). Stressful situations, including episodic failures of upwelling (e.g. El Niño events) as well as chronic changes in upwelling strength (e.g. regime shifts), can affect both the relative presence of live birds as well as their mortality, and thus their beaching rates (Bayer et al. 1991, Wilson 1991). At local scales, storm events, particularly in winter, are known to cause mortality spikes in marine bird populations, commonly referred to as winterkill (Schreiber 2002, Newton 2006). A combination of wind, wave, and thermal stress associated with storm events causes birds to exert more energy to survive at the same time that local food sources may become more difficult to find (Finney et al. 1999). Finally, when marine birds die at sea, they become surface drifters, influenced by both surface currents and local winds (Granadeiro \& Silva 1993, Flint \& Fowler 1998, Wiese 2003).

\section{Study system}

The California Current System (CCS) is an eastern boundary current system that extends from Vancouver Island to Baja California and is home to millions of seabirds, including both resident breeders and winter migrants (Briggs et al. 1987). In most years, equatorward upwelling winds prevail in the spring and summer. When surface currents are directed offshore and upwelling is strong, colder, saltier, and nutrient-rich waters dominate the nearshore along the US West Coast (Huyer 1983), resulting in a highly productive coastal ecosystem (Roemmich \& McGowan 1995). Downwelling prevails in fall and winter, with the most intense downwelling typically found in the northern half of the CCS. The wind-forced 'spring transition' from winter to summer conditions is frequently a sudden event (Strub et al. 1987), bringing distinct changes in coastal sea level, surface currents, nutrients, and nearshore sea surface temperatures along the entire west coast (Huyer 1983).

\section{The 2005 anomaly}

In 2005, there were widespread anomalies in the physical and biological properties of the CCS. Prominent characteristics included a mild winter and weak downwelling winds over the northern part of the CCS, but an anomalously stormy winter over the southern and central CCS (Gleason 2006). Spring brought winter-like conditions to the northern CCS, including a high frequency of downwelling wind periods that persisted until late May (Barth et al. 2007). In contrast, winds were favorable to upwelling, albeit weakly so, off the California coast from March to May (Schwing et al. 2006). At $45^{\circ} \mathrm{N}$, the spring transition to upwelling winds and surface currents came on May 24, some $50 \mathrm{~d}$ later than the long-term average (Kosro et al. 2006). However, a 'biological spring transition' was delayed an additional $50 \mathrm{~d}$ off Newport, Oregon, until subsurface upwelled water first penetrated the strongly stratified surface layer on July 13 (Kosro et al. 2006). The biological responses to delayed upwelling included anomalously low primary production, low recruitment of intertidal invertebrates (Barth et al. 2007), an intrusion of southern copepod species into northern CCS pelagic communities (Mackas et al. 2006), shifts in pelagic fish communities (Brodeur et al. 2006), and a breeding failure of Cassin's auklets Ptychorhamphus aleuticus in Central California (Sydeman et al. 2006).

The present paper explores seabird die-offs within the central and northern CCS in 2005, using beached bird data from 3 programs spanning from Monterey Bay, California, to Cape Flattery, Washington (Fig. 1). In particular, we establish the geographic and temporal scope of 2005 patterns relative to long-term averages, and examine the correlation between seasonal physical factors and species-specific elevations in beaching rate.

\section{MATERIALS AND METHODS}

Beached bird data. Beached bird data were collected from 3 regional programs: in Washington by the Coastal Observation and Seabird Survey Team (COASST) program; in Oregon by Robert Loeffel, a retired Oregon Department of Fish and Wildlife biologist, who maintains a long-term beached bird survey in Newport; and in Central California by the Coastal 
Fig. 1. US West Coast and north and central California Current System with locations of the 3 beached bird data sets (COASST, Loeffel, BeachCOMBERS) used in the present study

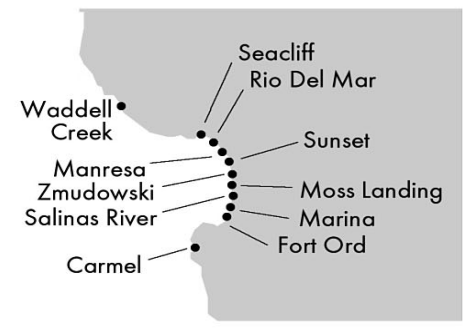

Ocean Mammal and Bird Education and Research Surveys (BeachCOMBERS) program in Monterey Bay (Fig. 1). For all programs, trained individuals surveyed predefined lengths of beach from one to several times monthly in most to all months of the year. All carcasses found during a survey were identified to the lowest possible taxon using keys specific to beachcast birds (Ainley et al. 1993, Hass \& Parrish 2002) and carcasses were marked or removed to avoid recounting.

In Washington, COASST volunteers conducted surveys monthly on dates of their choosing, such that between-survey intervals were roughly equivalent for each site. All carcasses were individually marked, photographed, and left on the beach. COASST sites were grouped into 2 regions: the south coast of Washington (Columbia River to Copalis River; 12 sites) and the north coast of Washington (Copalis River to Cape Flattery; 16 sites). Data span from November 2000 to December 2005.

In Oregon, surveys were largely performed by a single individual (Robert Loeffel), with assistance from a small group of trained assistants. From 1980 to 1983, surveys were performed at a jogging pace and flotsam piles were not searched, potentially leading to underrepresentation of carcasses in the data. After 1983, protocols were standardized to a walking pace. Exploration of the data revealed that carcass counts of study species were not significantly different across this pro-

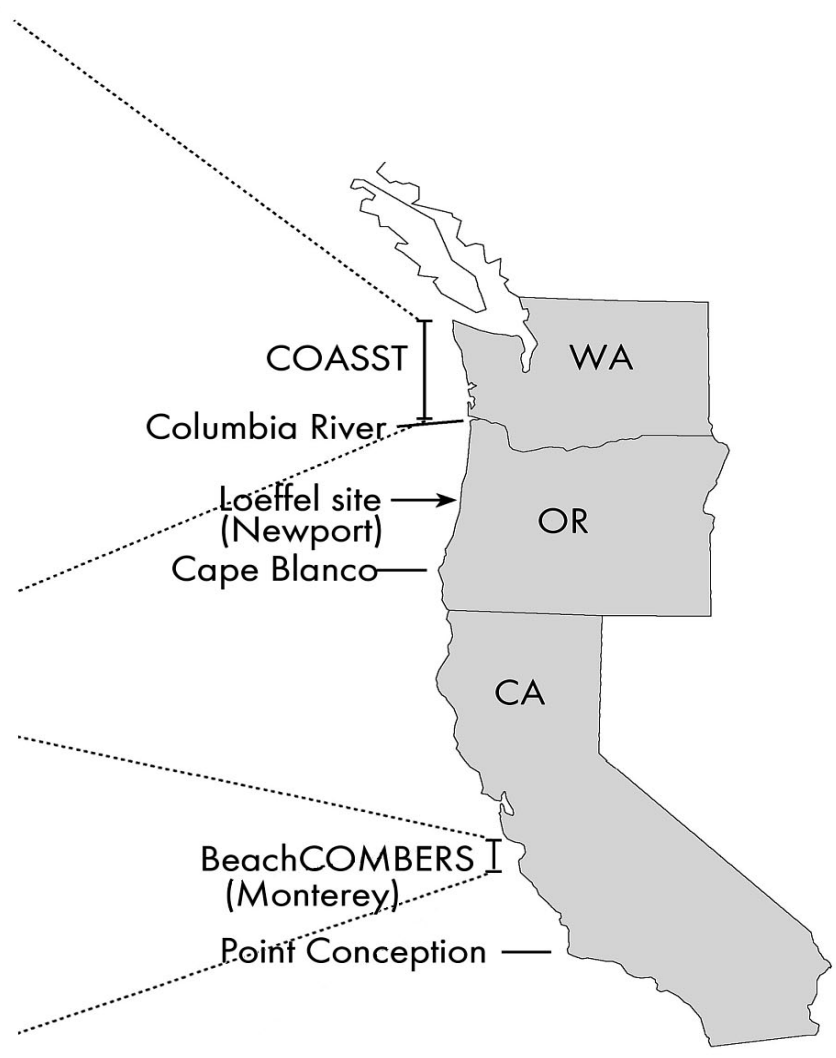

tocol change, so all data were used. Two beach sites totaling $7.4 \mathrm{~km}$ (Henderson Creek to Thiel Creek and Thiel Creek to Beaver Creek) near Newport, Oregon, were surveyed most consistently and were used in this analysis. Only surveys within $3 \mathrm{~d}$ of each other were used. Total carcasses were summed within month and divided by number of surveys to calculate average carcasses encountered per month. Data span from January 1980 to December 2005.

In Central California, BeachCOMBERS conducted monthly surveys at 11 beach segments of 3.7 to $5.2 \mathrm{~km}$ in length within the Monterey Bay National Marine Sanctuary (total $=51.1 \mathrm{~km}$ ). During the first week of each month, 2 trained surveyors working during an ebbing tide recorded all carcasses using a modified strip transect search pattern. Survey effort was centered on the wrack line of the previous high tide, and surveyors used binoculars to scan upper beach wrack for distant carcasses. Unidentified species were collected or photographed to verify identification. Data span from May 1997 to December 2005.

Species of interest. We chose to examine trends of 4 species (1) for which enough data were available to detect trends in depositional patterns (i.e. $>10 \%$ of species composition across survey regions), (2) which maximized trophic diversity, and (3) which accounted for the majority of anomalous die-offs recorded in 2005. We excluded the highly migratory species, such 
as shearwaters and fulmars, which may have been affected by extrinsic factors occurring outside the study area.

Cassin's auklets Ptychorhamphus aleuticus are smallbodied divers that consume mainly zooplankton. An estimated 3.5 million Cassin's auklets breed along the entire West Coast, with a population concentration in British Columbia ( 75\%; Manuwal \& Thoreson 1993). Cassin's auklets apparently migrate south in late fall to winter off California (Briggs et al. 1987), returning to colonies by March (Bertram et al. 2005).

Rhinoceros auklets Cerorhinca monocerata are actually puffins and feed on a mixture of fish and large zooplankton. As with Cassin's auklets, this species breeds from southern California to Alaska, but the vast majority of the West Coast population, nearly 1 million birds, is found in Washington and further north (Gaston \& Dechesne 1996). During winter, rhinoceros auklets migrate south, hundreds of thousands of them aggregating off California, north of Point Conception (Briggs et al. 1987). By April or May, these birds have returned to northern breeding sites.

Upwards of 4 million common murres Uria aalge, a deep-diving piscivore, are found along the West Coast. The population has a bimodal distribution, with breeding centers in northern California through northern Oregon $(24 \%)$ and in Alaska ( 70\%; Ainley et al. 2002). The post-breeding distribution is poorly known, although a general movement to inshore waters within the CCS, including Monterey Bay and the Strait of Juan de Fuca, has been noted (Briggs et al. 1987).

Brandt's cormorant Phalacrocorax pencillatus is the largest of the 4 focal species. A shallow-diving piscivore, Brandt's cormorant is found throughout the CCS, with thousands breeding in Oregon and tens of thousands concentrated in Central and Southern California (Wallace \& Wallace 1998). During the non-breeding season, Brandt's cormorants extend their range north, where large numbers overwinter in Washington and British Columbia, migrating south in April through June.

Analyses. Data from all 3 programs were standardized by beach length, as carcasses $\mathrm{km}^{-1} \mathrm{mo}^{-1}$, to create species-specific monthly encounter rates (a proxy for deposition), the basic unit of data for all analyses. Data are presented in 3 forms: (1) program means, $\mathrm{mo}^{-1}$, for each species and region, standardized to maximum monthly values (at 100\%), (2) 2005 monthly anomalies, calculated as the monthly encounter rate minus the monthly program mean, and (3) cumulative seasonal values, $\mathrm{yr}^{-1}$.

Based on the background pattern of beaching and the timing of physical change in the CCS system, we divided the data into 3 seasonal groupings: winter (November to February), spring (March to June), and summer (July to October). During winter, the down- welling signal is strongest in the northern CCS, the upwelling signal is weakest in the central to southern CCS (Huyer 1983), and storm events are most likely to occur. During this time, all 4 bird species are found in high numbers in the southern CCS, particularly at wintering sites such as Monterey Bay. The transition from winter to spring is punctuated by the annual departure of the 2 species of auklets to breeding colonies in the northern CCS and beyond and a switch in ocean conditions from predominantly downwelling to predominantly upwelling (i.e. the spring transition). During spring, murres and cormorants return to breeding colonies within the CCS. Summer is post-breeding, when northern breeders (auklets) migrate into the southern CCS.

Long-term program means were contrasted to the 2005 data, using 1-sample, 2 -sided $t$-tests. Correlation coefficients were used to explore concordance between select species $\times$ seasons and a range of physical and biological factors. These analyses were restricted to the Loeffel ( 26 yr) and BeachCOMBERS ( 8 yr) data sets, as the COASST data have only been gathered for 5 yr. Linear relationships are reported, unless exponential or power relationships explained an additional $10 \%$ or more of the variation.

Physical data. We used 3 indices of regional physical forcing: upwelling, vertical velocity, and zonal winds. Daily index values were summed over November to February and March to June. We chose from 1980 to 2005 to reflect the longest-running beached bird data set (Loeffel data from Newport, OR).

Upwelling indices along the US West Coast (www. pfeg.noaa.gov) are derived from sea level pressure (SLP) distributions and reflect the along-shore wind stress (Schwing et al. 1996). Cumulative seasonal values were used to characterize the mean forcing of cross-shore Ekman transports in the coastal zone, where positive values indicate upwelling and negative values indicate downwelling. We used the day of the year of spring transition as the onset of seasonal upwelling (Kosro et al. 2006).

We created a winter storminess index from the National Centers for Environmental Prediction (NCEP) National Center for Atmospheric Research Reanalysis project (Kistler 2001; www.cdc.noaa.gov/cgi-bin/db search/SearchMenus.pl). This data set was produced using a numerical weather prediction model assimilating surface, upper-air, and satellite-based observations for the period 1948 to the present. We used daily values of the pressure vertical velocity $(\omega)$ at $500 \mathrm{hPa}$ for $6^{\circ}$ latitude by $6^{\circ}$ longitude boxes, centered 3 degrees offshore of Monterey and Newport, to characterize high-frequency storm activity (e.g. Norris 2000). Negative values indicate upward vertical velocities, hence more stormy conditions overall. 
From the same source, and for the same spatiotemporal interval, mean zonal winds at the $300 \mathrm{hPa}$ (jet-stream level) were also considered. These winds represent a measure of the regional atmospheric circulation. Seasonal mean anomalies in the zonal winds aloft correspond with their counterparts at the surface $(\mathrm{r} \approx 0.7$ to 0.8 ). Westerly (easterly) wind anomalies aloft tend to be accompanied not only by downwelling (upwelling) anomalies at the coast (Barth et al. 2007), but also by equatorward (poleward) Ekman transports. The latter mechanism is potentially a significant influence on the latitude of the transition zone between sub-tropical and sub-arctic water masses and their attendant biological communities.

To explore a more local scale of physical forcing during the winter, we used hourly average surface wind speed and direction data obtained from the National Data Buoy Center website (http://ndbc.noaa.gov) for Station 46042 (27 nautical miles west of Monterey Bay, California) for 1997 to 2005 and Station NWPOB (Newport South Jetty, Newport, Oregon) for 1991 to 2005. Daily averages of the hourly wind speed squared (the pseudo-stress magnitude, in $\mathrm{m}^{2} \mathrm{~s}^{-2}$ ) were computed from the hourly data using all available observations for each day at each station, respectively. Within the November through February period, for years in which data were constantly available, we chose all days in which mean pseudo-stress was 0.5 standard deviations or more above the long-term winter mean. We called these events storms; they lasted one to several days. We also examined more extreme storms, defined as those events exceeding a daily pseudo-stress of $10 \mathrm{~m}^{2} \mathrm{~s}^{-2}$. Finally, we tallied the number of days across the 4 mo winter season that winds were directed on-shore (180 to $270^{\circ}$ ). For each winter, we recorded the number of storms, the average duration (in days), the average daily intensity $\left(\mathrm{m}^{2} \mathrm{~s}^{-2}\right)$, the maximum event intensity (cumulative $\mathrm{m}^{2} \mathrm{~s}^{-2}$ over the storm), and the frequency of on-shore winds (days). The data set from Monterey was complete; however, the data from Newport had gaps such that the winters of 1997 and 1998 were excluded.

Biological data. We used biweekly, inner-shelf, copepod biomass (mg carbon $\mathrm{m}^{-3}$ of water sampled) data collected at a single station (NH-05, 5 nautical miles offshore) along the Newport Line $\left(44.5^{\circ} \mathrm{N}\right)$, with a $0.20 \mathrm{~mm}$ vertical ring net towed from the bottom to the surface (Peterson \& Keister 2003). Data were simplified to a single index - the $x$-axis ordination scores of a non-metric multidimensional scaling (NMDS), using Sorensen's distance measure and incorporating logtransformed species abundance versus sample date (including 1969 to 1973, 1983, and 1996 to 2007). Rare species (occurring in $<5$ samples) were not included. In this measure, negative values correspond to cold water conditions and northern species (e.g. Pseudocalanus mimus, Acartia longiremis, Calanus marshallae) and positive values represent warmer water southern species (e.g. Paracalanus parvus, Ctenocalanus vanus, Mesocalanus tenuicornis, Clausocalanus spp.). Monthly index values were summed over relevant months during the spring to summer period (March through June). Winter months contained too many years with 1 or more missing monthly sample to be useful.

\section{RESULTS}

\section{Regional patterns of beaching}

Along the US West Coast, baseline beaching rates for 3 of the 4 focal species were remarkably similar; the exception was Cassin's auklet Ptychorhamphus aleuticus (Fig. 2B). Post-breeding mortality peaks (July to October) were evident for the rhinoceros auklet Cerorhinca monocerata and the common murre Uria aalge (Fig. 2A,C). For murres, a shift in the peak of mortality from south to north followed the shift in the timing of breeding for this species. The post-breeding signal was slightly modified in California by the summer gill net mortality that occurred in 1997 to 2000 (Forney et al. 2001). Rhinoceros auklet beaching peaked in the northern CCS during August to September, but was maximal in Monterey much earlier (April). This shift may represent earlier breeding in the south, or potentially mortality of northward migrating birds.

In northern Washington and Oregon, Brandt's cormorant Phalacrocorax pencillatus mortality peaked during the post-breeding season (August to September); however, in southern Washington and California the peak fell much earlier, in April to May (Fig. 2D). The California peak may be indicative of earlier breeding; however, the breeding range of this species is largely exclusive of the Washington coastline (Wallace \& Wallace 1998), making the southern Washington early season peak more difficult to explain.

Clear baseline patterns were least apparent for Cassin's auklets; however, the beaching rate was typically very low for this species (i.e. $<0.05$ birds $\mathrm{km}^{-1}$ ). Although a suggestion of CCS post-breeding peaks existed for the Washington and Oregon data, in California the peak fell much earlier, during April (Fig. 2A). This earlier peak coincided with the mortality peak in rhinoceros auklets in the same region, suggesting a location effect. Finally, all 4 locations showed winterkill.

\section{The 2005 die-off}

In 2005, anomalously high beaching rates for all 4 resident species were concentrated (1) in the winter 


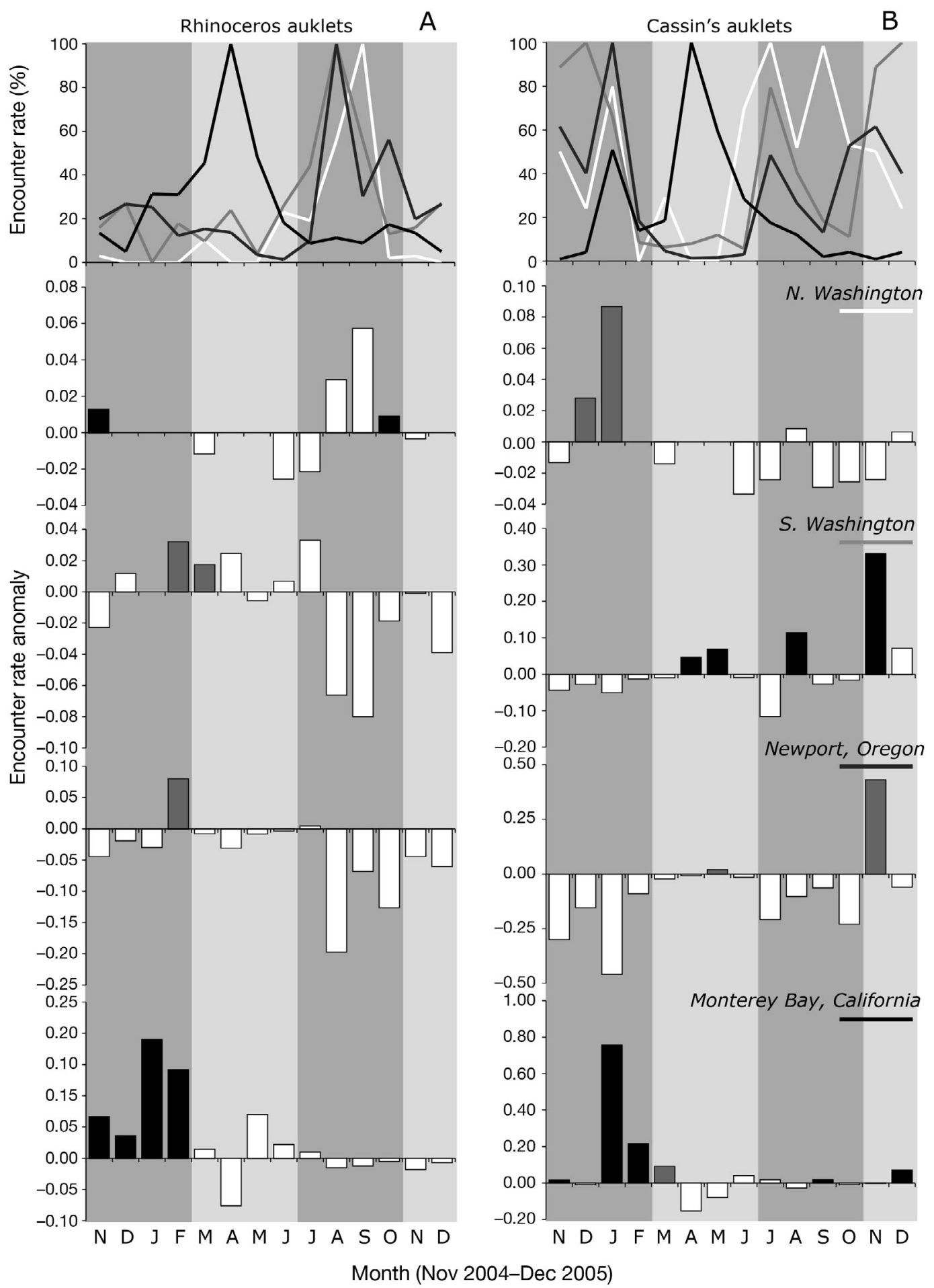

Fig. 2. (Above and facing page.) Encounter rates of (A) rhinoceros auklets, (B) Cassin's auklets, (C) common murres, and (D) Brandt's cormorants across the 4 sampling locations. Top row of panels: the average monthly encounter rate (a proxy for deposition) over the history of each program, standardized to maximum monthly value (at $100 \%$ ) within each program. Northern Washington: white; southern Washington: light gray; Newport: dark gray; Monterey: black. Note that the 2 overlapping months (November, December) have the same mean values in the top panel graphs. Lower rows of panels: the encounter anomaly (month - mean), in birds km-1, for each of the 4 sampling locations (as listed) for November 2004 through December 2005. For positive anomalies, individual month between 120 and $300 \%$ of the mean value are shaded gray; anomalies $>300 \%$ of the mean are in black. Background shading separates seasonal groupings used in the analysis: winter (November to February), spring to summer (March to June), and post-breeding (July to October) 

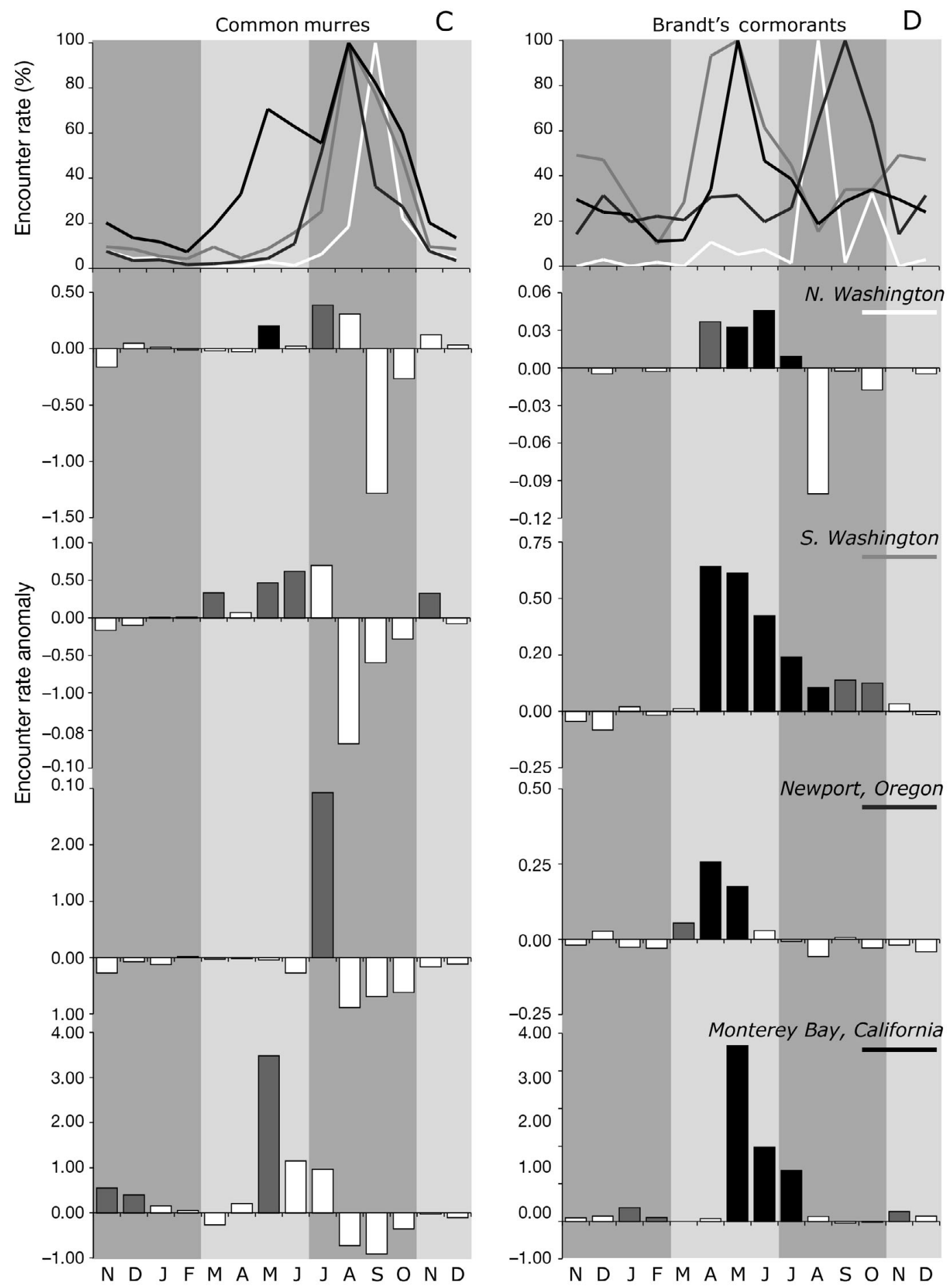

Month (Nov 2004-Dec 2005)

Fig. 2 (continued)

and spring, (2) in the piscivorous species, and (3) especially in the southernmost location (California; Fig. 1). Rhinoceros auklets and Cassin's auklets, the 2 zooplanktivorous species, beached primarily during the winter in California (Fig. 2A,B, Table 1). For Cassin's auklets especially, anomalously high beaching resulted in an abundance of carcasses, as the underlying mean values during winter (particularly in January) were already high (Fig. 2B). In the northern CCS, these species either did not beach in appreciable numbers, or 
Table 1. Comparison of 2005 seasonal beaching rates versus program average values (1-sample, 2 -sided $t$-tests). Negative, significant $t$-values (indicating higher than expected beaching) are bold. Positive, significant $t$-values (indicating lower than expected beaching) are bold and italicized. Sample sizes (n), in years, are listed following each location. COMU: common murre Uria aalge; BRAC: Brandt's cormorant Phalacrocorax pencillatus; RHAU: rhinoceros auklet Cerorhinca monocerata; CAAU: Cassin's auklet Ptychorhamphus aleuticus; winter: November to February; spring-summer: March to June; post-breeding: July to October; n.s.: not significant

\begin{tabular}{|c|c|c|c|c|c|c|c|c|}
\hline & \multicolumn{2}{|c|}{ COMU } & \multicolumn{2}{|c|}{ BRAC } & \multicolumn{2}{|c|}{ RHAU } & \multicolumn{2}{|c|}{ CAAU } \\
\hline & $t$ & $\mathrm{p}$ & $t$ & $\mathrm{p}$ & $t$ & $\mathrm{p}$ & $t$ & $\mathrm{p}$ \\
\hline \multicolumn{9}{|c|}{ North coast, WA $(n=5)$} \\
\hline Winter & 1.852 & n.s. & 1.633 & n.s. & -3.000 & n.s. & -2.379 & n.s. \\
\hline Spring-Summer & -3.707 & $<0.05$ & -3.920 & $<0.05$ & 1.471 & n.s. & 1.615 & n.s. \\
\hline Post-breeding & 0.659 & n.s. & 1.235 & n.s. & -0.751 & n.s. & 1.513 & n.s. \\
\hline \multicolumn{9}{|c|}{ South coast, WA $(n=5)$} \\
\hline Fall-Winter & 1.283 & n.s. & 1.539 & n.s. & -0.145 & n.s. & 0.509 & n.s. \\
\hline Spring-Summer & -3.600 & $<0.05$ & -3.989 & $<0.05$ & -1.355 & n.s. & -3.823 & $<0.05$ \\
\hline Post-breeding & 1.442 & n.s. & -3.984 & $<0.02$ & 1.652 & n.s. & 0.585 & n.s. \\
\hline \multicolumn{9}{|c|}{ Newport, OR $(n=25,26)$} \\
\hline Winter & 2.895 & $<0.01$ & 2.328 & $<0.05$ & 0.448 & n.s. & 1.888 & n.s. \\
\hline Spring-Summer & 2.049 & n.s. & -19.641 & $<0.0001$ & 2.163 & $<0.05$ & 2.090 & $<0.05$ \\
\hline Post-breeding & -0.723 & n.s. & 1.999 & n.s. & 3.778 & $<0.001$ & 1.918 & n.s. \\
\hline \multicolumn{9}{|c|}{ Monterey, CA (n= 8) } \\
\hline Winter & -5.088 & $<0.002$ & -3.951 & $<0.01$ & -6.838 & $<0.001$ & -6.998 & $<0.001)$ \\
\hline Spring-Summer & -3.366 & $<0.01$ & -6.931 & $<0.001$ & -0.142 & n.s. & 0.310 & n.s. \\
\hline Post-breeding & 0.728 & n.s. & -5.985 & 0.001 & 1.529 & n.s. & 0.061 & n.s. \\
\hline
\end{tabular}

experienced only scattered anomalously high months. By spring, beaching of the auklet species had either returned to normal values, or values were actually significantly less than expected (Oregon; Fig. 2, Table 1).

Common murre and Brandt's cormorant beaching was somewhat elevated during the winter, but only in California (Fig. 2C,D, Table 1). In the northern CCS, beaching rates were either normal (Washington) or actually significantly lower than expected during the winter (Oregon; Fig. 2, Table 1). However, by spring both of these species were washing up in significant numbers throughout their breeding range (Fig. 2, Table 1). Normally, peak murre beaching rates occur during the post-breeding period (Fig. 2C, top panel). Thus, the 2005 murre mortality event occurred unseasonably early. Even in Oregon, where beaching rates were normal during spring, a large anomaly in July preceded the usual annual peak by a month (July 2005 versus the long-term mean, $t=-8.466, \mathrm{p}<0.0001$; Fig. $2 \mathrm{C}$ ). By the post-breeding season, mortality rates had returned to normal mean values, and individual months fell well below normal peak values.

By far, the strongest and longest spring mortality anomaly came from Brandt's cormorants (Fig. 2D, Table 1). All 4 locations registered significant increases in the carcasses of these cormorants during spring to summer, irrespective of whether peak mortalities were expected (southern Washington, California) or not (northern Washington, Oregon; Fig. 2D, top panel). Unseasonably high beaching continued through the beginning of the post-breeding season in southern Washington and California (Fig. 2D, Table 1).

\section{Exploring bio-physical linkages}

Given the 2005 die-off events, 3 basic mechanisms might explain anomalously high deposition of birds on beaches in the CCS: (1) physical stress increased on-water mortality rates, (2) physical forcing acted through bottom-up food web processes, and (3) physical forcing altered the rate at which carcasses were delivered to shore. These are not mutually exclusive; however, each leads to different hypotheses. If direct physical stress increased mortality, we predicted that in years with a higher frequency, duration, or intensity of storm events, and/or years with an elevated regional storminess index, beaching rates would be higher. If physical forcing acted through food web processes, we predicted that in years with negative zonal winds, beaching rates might be higher, as Ekman processes drove the sub-arctic-sub-tropical transition to the north. Food web structure and biomass would also be negatively affected by a late transition to upwelling and/or years in which spring upwelling was relatively weak. Because the cycle of strong upwelling along the West Coast occurs in spring, after the auklets have largely migrated north out of the system, we restricted this latter hypothesis to the predominantly local breeders, common murres and Brandt's cormorants. Finally, if physical forcing changed the rate at which drifters (aka carcasses) were delivered to shore, we predicted that in years in which cumulative downwelling was stronger, beaching rates would be higher. Because downwelling occurs concurrently with storm events, it is not entirely possible to tease apart the direct and 
Table 2. Correlation coefficients $\left(\mathrm{R}^{2}\right)$ between cumulative encounter rates (birds km${ }^{-1}$ ) during the winter (November to February), and a range of proxies of regional and local winter conditions. Relationships in a direction other than expected given hypotheses (see 'Results, Exploring bio-physical linkages, Winter') are in italics. Sample size (n), in yr, is listed following each location. For local buoy wind data, Monterey sample size was 7 (1999 to 2005). For Newport, sample size was 12 (1992 to 1996 , 1999 to 2005) due to missing data months in all other inclusive years. See Table 1 for taxonomic names

\begin{tabular}{|c|c|c|c|c|c|c|c|c|}
\hline & \multirow{2}{*}{$\begin{array}{l}\text { Zonal } \\
\text { winds }\end{array}$} & \multirow{2}{*}{$\begin{array}{l}\text { Vertical } \\
\text { velocity }\end{array}$} & \multirow{2}{*}{$\begin{array}{l}\text { Upwelling } \\
\text { index }\end{array}$} & \multirow[b]{2}{*}{$\begin{array}{l}\text { Duration } \\
\text { mean }(d)\end{array}$} & \multicolumn{3}{|c|}{ _Buoy data } & \multirow[b]{2}{*}{$\begin{array}{l}\text { Intensity max } \\
\left(\mathrm{m}^{2} \mathrm{~s}^{-2}\right)\end{array}$} \\
\hline & & & & & $\begin{array}{l}\text { Onshore } \\
\text { wind (d) }\end{array}$ & $\begin{array}{l}\text { Number } \\
\text { of storms }\end{array}$ & $\begin{array}{c}\text { Intensity mean } \\
\left(\mathrm{m}^{2} \mathrm{~s}^{-2}\right)\end{array}$ & \\
\hline \multicolumn{9}{|l|}{ Monterey, CA (n= 8) } \\
\hline Common murres & 0.202 & 0.432 & 0.237 & 0.024 & 0.098 & 0.018 & 0.033 & 0.000 \\
\hline Brandt's cormorants & 0.544 & 0.140 & 0.041 & 0.080 & 0.004 & 0.388 & 0.005 & 0.094 \\
\hline Rhinoceros auklets & 0.388 & 0.001 & 0.018 & 0.197 & 0.379 & 0.001 & 0.082 & 0.165 \\
\hline \multicolumn{9}{|l|}{ Newport, OR $(n=25)$} \\
\hline Common murres & 0.038 & 0.103 & 0.071 & 0.080 & 0.095 & 0.035 & 0.058 & 0.044 \\
\hline Brandt's cormorants & 0.024 & 0.001 & 0.051 & 0.049 & 0.005 & 0.000 & 0.016 & 0.001 \\
\hline Rhinoceros auklets & 0.106 & 0.032 & 0.003 & 0.013 & 0.048 & 0.148 & 0.016 & 0.149 \\
\hline Cassin's auklets & 0.142 & 0.040 & 0.021 & 0.056 & 0.072 & 0.012 & 0.044 & 0.066 \\
\hline
\end{tabular}

indirect effects of storms. To explore which, if any, of these mechanisms might have been operating, we hindcast, using the 2 data sets with a longer timeline, i.e. California and Oregon, and examined the correlations among physical proxies of winter storms and spring upwelling, and beaching rates of each species within the relevant season.

\section{Winter}

In general, the influence of winter conditions on beaching rates of our 4 focal species appeared to be weak (Table 2). In California, we deleted Cassin's auklets from the analysis, as the majority of the years had beaching rates of zero. For the remaining 3 species, the strongest correlations were with zonal winds (Table 2), although no single physical variable was highly associated with beaching rates across all species. Cormorant, murre, and auklet beaching rates were higher when zonal winds were easterly (Table 2, Fig. 3A), possibly suggesting that northward Ekman transport may have disassociated the food web for these species. The 2005 data point was an outlier in all cases and drove the correlation in the case of auklets. Only murres had any association with the remaining regional-scale variables, vertical velocity (Fig. 3B) and upwelling index (not shown). In both cases, more murres beached in stormy (i.e. lower vertical velocity, stronger downwelling) years. Local storminess, at least as indicated by surface winds, had no influence on beaching rates, with the possible exception of frequency of onshore windy days and rhinoceros auklets (Table 2). However, this latter association was entirely driven by the 2005 point (large number of
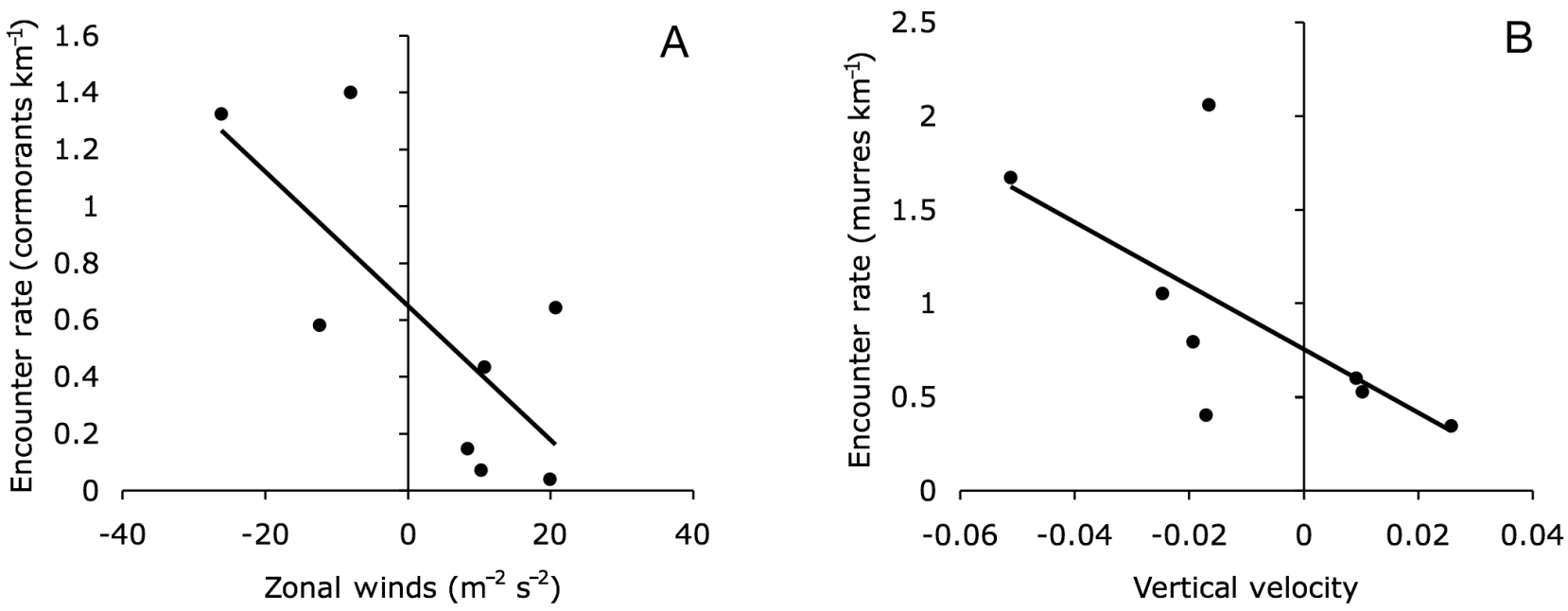

Fig. 3. Encounter rates of (A) Brandt's cormorants as a function of winter (November to February) zonal winds at $300 \mathrm{hPa}$ (where birds $=-0.0236$ zonal winds +0.650 ) and $(\mathrm{B})$ common murres as a function of winter (November to February) vertical velocity (where birds $=-16.94$ vertical velocity +0.755$)$, both within the Monterey, CA, site 
onshore windy days and high encounter rate); when this point is removed, the relationship weakens considerably. Lagging the data $1 \mathrm{mo}$, such that storminess in November through January influenced beaching rates in December through February did not improve the associations. Thresholding storms to only those events exceeding $10 \mathrm{~m}^{2} \mathrm{~s}^{-2}$ also had no effect on strengthening the association between the number, duration, or intensity of storms and seabird beaching. In Oregon, associations between winter physical variables and seabird beaching rates were essentially nonexistent (Table 2); beaching rates were entirely unresponsive to regional- or localscale variables.
Table 3. Correlation coefficients $\left(\mathrm{R}^{2}\right)$ between cumulative encounter rates (birds $\mathrm{km}^{-1}$ ) during spring to summer (MA: Mar and Apr; MAM: Mar to May; MAMJ: Mar to Jun), and a range of proxies of nearshore productivity during spring. Relationships in a direction other than expected (see Table 2) are in italics. Power $\left(y=c x^{b}\right)$ relationships are indicated by an asterisk; otherwise, all correlations are linear. Sample size (n), in yr, is listed following each location. See Table 1 for taxonomic names

\begin{tabular}{|c|c|c|c|c|c|c|}
\hline & \multirow{2}{*}{$\begin{array}{l}\text { Spring transition } \\
\text { (day of the year) }\end{array}$} & \multicolumn{3}{|c|}{ Upwelling index } & \multicolumn{2}{|c|}{ Copepod index } \\
\hline (da) & & $\mathrm{MA}$ & MAM & MAMJ & MA & MAM \\
\hline \multicolumn{7}{|l|}{ Monterey, CA (n = 8) } \\
\hline Common murres & 0.112 & $0.162^{*}$ & $0.656^{*}$ & $0.635^{*}$ & & \\
\hline Brandt's cormorants & 0.568 & $0.275^{*}$ & $0.710^{*}$ & $0.692^{*}$ & & \\
\hline \multicolumn{7}{|l|}{ Newport, OR $(n=26)$} \\
\hline Common murres & 0.002 & 0.078 & 0.036 & 0.021 & & \\
\hline Brandt's cormorants & 0.232 & 0.044 & 0.115 & 0.122 & & \\
\hline \multicolumn{7}{|c|}{ Newport, OR ( $\mathrm{n}=8 ; 9$ for copepod index) } \\
\hline Common murres & 0 & 0.050 & 0.036 & 0.139 & 0.138 & 0.176 \\
\hline Brandt's cormorants & 0.638 & 0.023 & 0.185 & 0.326 & 0.061 & 0.384 \\
\hline
\end{tabular}

\section{Spring to summer}

In California, both the timing and cumulative intensity of upwelling appeared to influence beaching rates of both species (Table 3), especially for Brandt's cor- morants. Later transitions and weaker upwelling were associated with higher deposition (Fig. 4), as would be expected if birds were starving as a result of altered nearshore productivity. Correlation coefficients between beaching and cumulative upwelling were sub-
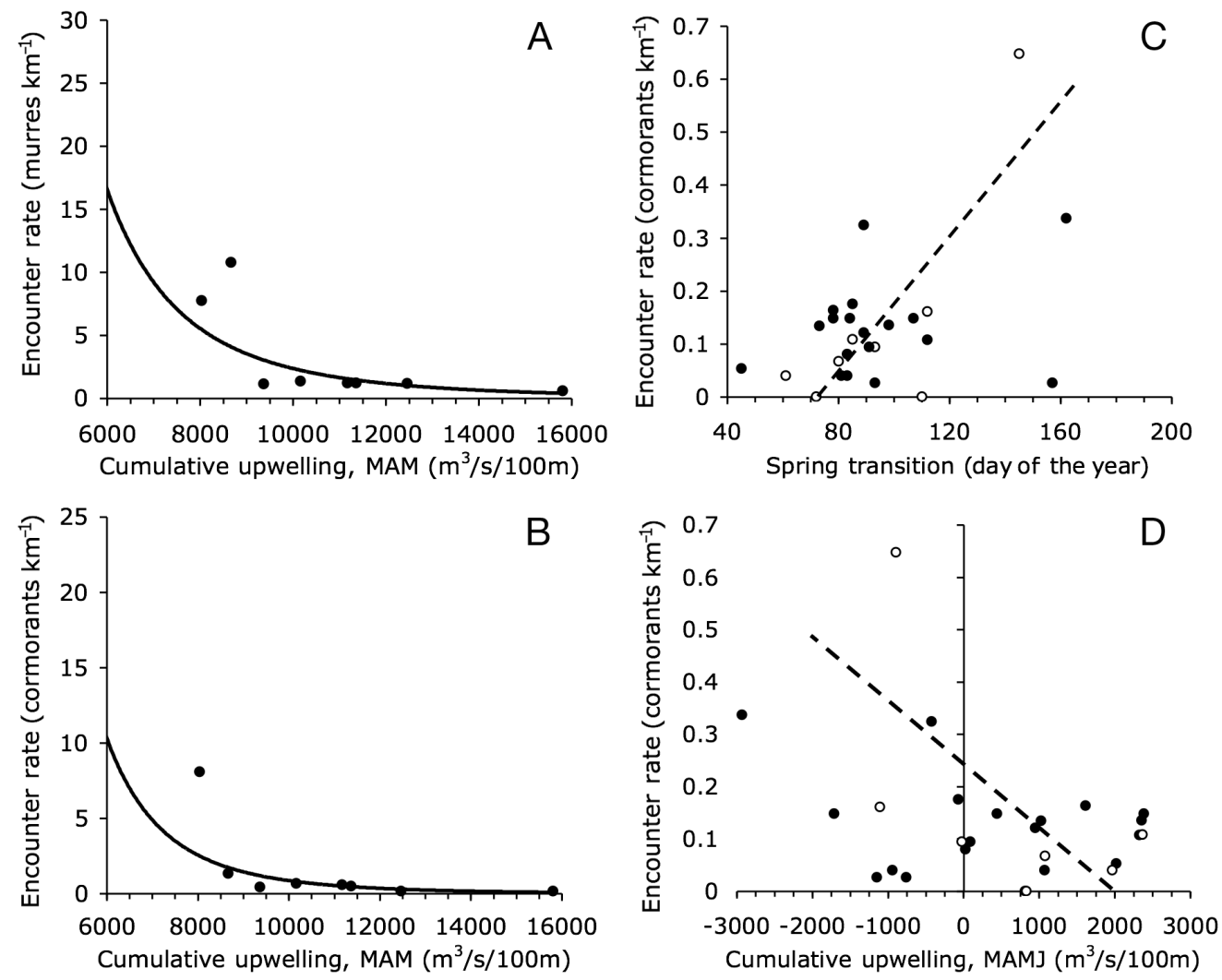

Fig. 4. Spring to summer (MAM: Mar to May, MAMJ: Mar to Jun) encounter rates of local breeders versus spring upwelling intensity (UW) and onset (ST). (A) Common murres in Monterey (birds $=[4 \mathrm{E}+15] \times \mathrm{UW}^{-3.7964}$ ), (B) Brandt's cormorants in Monterey (birds $\left.=[2 \mathrm{E}+19] \times \mathrm{UW}^{-4.8366}\right),(\mathrm{C})$ Brandt's cormorants in Newport (dashed line, 1998 to 2005: birds $\left.=0.0063 \mathrm{ST}+0.456\right)$, and (D) common murres in Newport (dashed line, 1998 to 2005: birds $=-0.0001 \mathrm{UW}+0.202$ ). Open circles in Panels C and D are 1998 to 2005 data 

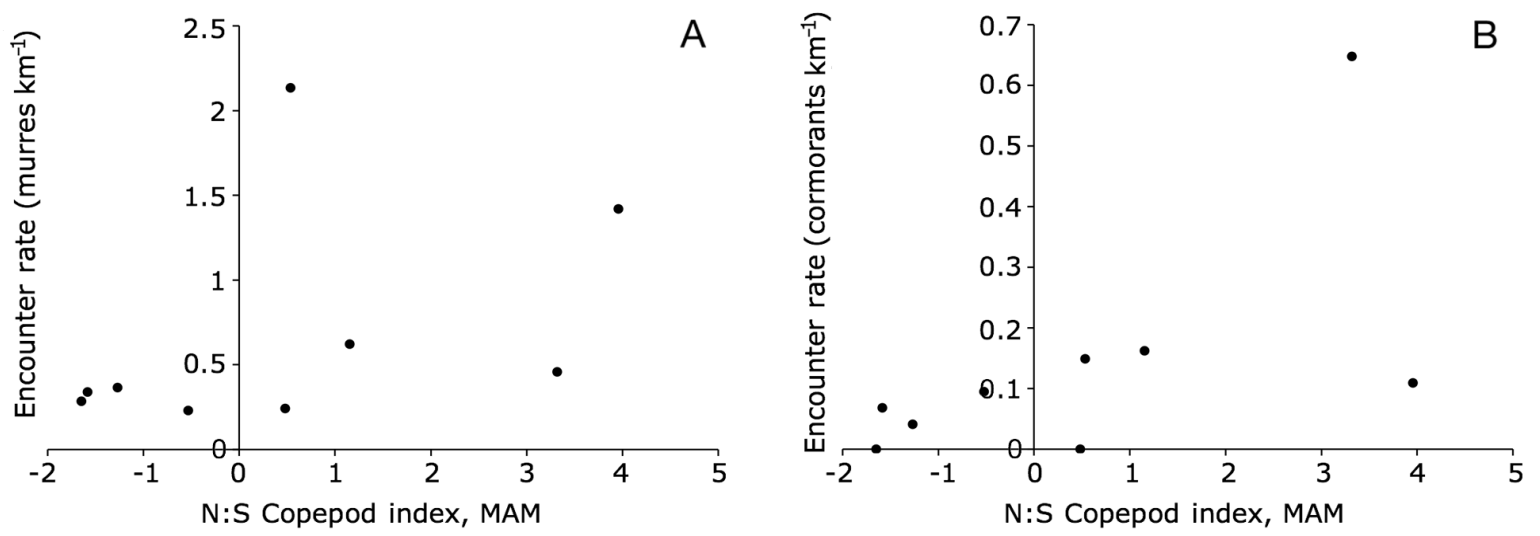

Fig. 5. Spring to summer (MAM: Mar to May) encounter rates of local breeders versus index of northern (negative) versus southern (positive) copepod community, 1997 to 2005. (A) Common murres in Newport and (B) Brandt's cormorants in Newport

stantially improved with a power model, suggesting that at the low end, only a slight additional weakening in upwelling was associated with a large biological response (Fig. 4A,B). In fact, the relationships appeared to be driven largely by these 'bad' bird years $(2005,1998)$. Removing these points from the data set destroyed the correlations. Finally, when cumulative upwelling was restricted to only early spring (March to April), correlations were lower for both species, perhaps indicating that early season physics did not necessarily set the stage for later beaching events, or that extended periods of weakened upwelling were necessary to provoke bottom-up indirect effects.

The strength of the association between spring to summer nearshore physics and seabird beaching rate was not, however, apparent in Oregon (Table 3, Fig. 4), with the possible exception of the timing of upwelling onset and Brandt's cormorants. To infer whether the lack of association was a result of meso-scale geographic differences (central versus northern CCS) and/or the difference in temporal scope (8 versus $26 \mathrm{yr}$ ), we also reran the correlations restricted to the 1998 to 2005 window. Shortening the time series did improve correlations between Brandt's cormorant beaching rates and both the intensity and, especially, onset timing of upwelling (Table 3, Fig. 4). As with the California results, later transition dates and weaker upwelling were associated with higher beaching rates. Correlations between murre and cormorant beaching, and the Newport line index of copepod diversity were stronger, albeit still weak (Table 3). As predicted, in years with a higher incidence of cold-water (i.e. northern) species in the zooplankton community, beaching rates were lower (Fig. 5). A southern community composition resulted in higher beaching rates, although high beaching was not restricted to only southern community-dominated years (e.g. 1997 for murres). Finally, the strength of the association was strongest when May was included in the copepod index value (Table 3).

\section{DISCUSSION}

The patterns found across the 3 beached bird data sets in 2005 appear to echo patterns described by anomalous ocean and atmospheric conditions reported by others (Schwing et al. 2006, Barth et al. 2007). Pervasive die-offs of Brandt's cormorant Phalacrocorax pencillatus and the common murre Uria aalge in the spring to summer reflected weak upwelling and the delay in both physical and biological spring transition (Kosro et al. 2006, Mackas et al. 2006). However, the elevated rate of auklet (Ptychorhamphus aleuticus, Cerorhinca monocerata) beaching in the central CCS during the winter and the apparent absence of common murre mortality in Oregon did not follow from known physical conditions.

Do the responses of birds to changing ocean conditions in 2005 fit a more general model of physical forcing of beached bird patterns? In general, annual deposition of common seabird species within the CCS were only weakly related to physical forcing factors. Correlations in the central CCS site-Monterey-were uniformly higher than those at the northern CCS siteNewport (Tables 2 \& 3). Associations were tighter between physical forcing and biological response in the spring relative to the winter (Tables $2 \& 3$ ). During the winter, only regional factors (i.e. zonal winds) appeared to influence all species, perhaps telescoping through the food web (e.g. Fig. 5). On the other hand, local winter forcing, typified by storm duration and intensity, did not appear to affect the timing or abundance of beaching (Table 2).

In exploring the potential linkages between physical forcing and beaching rates, we hypothesized 3 nonexclusive mechanisms: (1) increased mortality rates as a consequence of direct physical stress, (2) increased mortality rates as a consequence of bottom-up food web processes, and (3) increased delivery rate of carcasses to the beach. Our analyses suggest that direct 
physical stress, specifically winter storms, was not a strong factor affecting annual beaching rate (Table 2). In fact, only common murres at the California site showed any association with our regional storminess index, vertical velocity (Table 2 ). Thus, while is it certainly true that seabird beaching is higher during the winter (Camphuysen et al. 1999), there were no simple relationships between measures of storminess and bird beaching.

Bottom-up food web processes appeared to be the strongest signal in our data. Delays in the onset of seasonal upwelling and upwelling intensity were both associated with beaching in those species largely resident in the system, especially Brandt's cormorants (Table 3, Fig. 4). Changes in upwelling timing and intensity in eastern boundary current systems are well known forcing factors affecting system production, from primary productivity to upper trophic population dynamics (Barber \& Chavez 1983, Duffy et al. 1988, Ainley et al. 1995), so the apparent relationship to beaching rates is not surprising.

What was non-intuitive is the weak (cormorants) to non-existent (murres) association between upwelling and beaching rates at our northern CCS site. Restricting the analysis to only the Monterey data set interval improved the correlations for cormorants (Table 3), suggesting that decadal-scale shifts (e.g. Pacific Decadal Oscillation) may play a role in beached bird abundance. However, determining the degree of this potential association would require a time series exceeding our Oregon ( 26 yr) data. At the very least, these data, together with the shorter term COASST data, appear to suggest that beached birds may reflect the apparent physical differences from north to south within the CCS (e.g. Mueter et al. 2002).

One potentially important difference between Monterey and Newport is that seabirds aggregate at the former as a foraging and resting hotspot (Briggs et al. 1987), but only breed (especially cormorants and murres) at the latter. Thus, what ends up on the beach in Monterey versus Newport in the winter may reflect more of the post-breeding distribution-and thus, choices-of the live birds, rather than the local-toregional physics allowing carcasses to reach the beach. Thus, while extreme on-shore storms during the winter in Newport may create ready conditions for elevated carcass delivery, an observed increase in carcasses is only possible if there are birds in the area to suffer that mortality.

Food web processes were potentially invoked by the relationship between zonal winds and beaching rates, evident at the California, but not the Oregon, site. Here, the hypothesis is that easterly winds aloft may be associated with a northward shift in the extent of southern pelagic communities. Although our analysis suggested that birds washed ashore in years with a predicted northward shift (Monterey in winter; Table 2) and that southern copepods were more abundant and northern copepods were less abundant in years with higher bird beaching (Newport in spring; Table 3); this thread falls across 2 sites and 2 seasons, making direct conclusions suspect. Barth et al. (2007) have suggested that winds aloft can be related to changes in the strength and onset of coastal upwelling-particularly in 2005-thus, this mechanism may also explain elevated spring to summer beaching rates.

Finally, we found no direct evidence that physical processes resulted in a change in the rate of carcass delivery to the beach. With the possible exception of murres, increased winter downwelling did not result in higher carcass abundances (Table 2), and neither did years with more abundant on-shore wind days (Table 2). Wiese \& Ryan (2003) did find a significant effect of weather index (first principal component of air temperature, wind direction, and wind velocity) on beaching rates of oiled carcasses in Newfoundland. During colder months, with stronger on-shore winds, more carcasses came ashore, indicating that at least in some areas local physical forcing assessed monthly may play a role in regulating carcass delivery. The dominant variability in wind forcing over the CCS occurs at time scales of several days (Hickey 1989). Eventscale reversals in wind direction on the order of 5 to $7 \mathrm{~d}$ (Hickey \& Banas 2003) cause drifters (and thus potentially carcasses) to move towards (away from) the coastal zone (MacFadyen et al. 2005). Thus, it is possible that the temporal scale at which the beached bird data were collected (aggregated monthly) is not sufficient to distinguish the relationship between physical processes and carcass delivery rates.

Are beached birds good indicators of ocean conditions? The present paper has clearly demonstrated that, although the answer can be yes, it is not necessarily so. This indicates that the forces provoking movement in the live bird populations, as well as the physics of birds as drifters, must be understood at local-toregional levels in order to comprehend the beached bird signal. Having said that, it is also clear that during 2005 anomalous conditions in the physical environment resulted in a dramatic and non-linear response across the seabird community, with the end result that an additional amount of tens of thousands of bird carcasses beached along the CCS during spring and early summer.

Acknowledgements. The authors thank the many hundreds of BeachCOMBERS and COASST volunteers who have diligently collected monthly data. J. Dolliver and K. Litle provided assistance in preparing the manuscript. Funding for 
BeachCOMBERS came from the Monterey Bay National Marine Sanctuary Foundation. Funding for COASST came from Olympic Coast National Marine Sanctuary, Alaska and Northwest Fisheries Science Centers, Oregon Department of Land Conservation and Development, Washington Department of Fish and Wildlife, North Pacific Research Board, David and Lucille Packard Foundation, The Russell Family Foundation, and private donors. The manuscript was greatly improved by A. Burger and one anonymous reviewer.

\section{LITERATURE CITED}

Ainley DG, Jones RE, Stallcup R, Long DJ and others (1993) Beached marine birds and mammals of the North American west coast: a revised guide to their census and identification, with supplemental keys to beached sea turtles and sharks. National Oceanic and Atmospheric Administration, San Francisco, CA

Ainley DG, Sydeman WJ, Norton J (1995) Upper trophic level predators indicate interannual negative and positive anomalies in the California Current food web. Mar Ecol Prog Ser 118:69-79

Ainley DG, Nettleship DN, Carter HR, Storey AE (2002) Common murre (Uria aalge). In: Poole A, Gill F (eds) The birds of North America, No. 666. The Birds of North America, Philadelphia, PA

Anderson PJ, Piatt JF (1999) Community reorganization in the Gulf of Alaska following ocean climate regime shift. Mar Ecol Prog Ser 189:117-123

Barber RT, Chavez FP (1983) Biological consequences of El Niño. Science 222:1203-1210

Barth JA, Menge BA, Lubchenco J, Chan F and others (2007) Delayed upwelling alters nearshore coastal ocean ecosystems in the northern California Current. Proc Natl Acad Sci USA 104:3719-3724

Bayer RD, Lowe RW, Loeffel RE (1991) Persistent summer mortalities of common murres along the Oregon central coast. Condor 93:516-525

Bertram DF, Harfenist A, Smith BD (2005) Ocean climate and El Niño impacts on survival of Cassin's auklets from upwelling and downwelling domains of British Columbia. Can J Fish Aquat Sci 62:2841-2853

Briggs KT, Tyler WB, Lewis DB, Carlson DR (1987) Bird communities at sea off California: 1975-1983. Stud Avian Biol 11:1-79

Brodeur RD, Ralston S, Emmett RL, Trudel M, Auth TD, Phillips AJ (2006) Anomalous pelagic nekton abundance, distribution, and apparent recruitment in the northern California Current in 2004 and 2005. Geophys Res Lett 33:L22S08

Camphuysen KCJ, Wright PJ, Leopold M, Hüppop O, Reid JB (1999) A review of the causes, and consequences at the population level, of mass mortalities of seabirds ICES Coop Res Rep 232:51-62

Duffy DC, Arntz WE, Serpa HT, Boersma PD, Norton RL (1988) A comparison of the effects of El Niño and the Southern Oscillation on birds in Peru and the Atlantic Ocean. In: Ouellet H (ed) Acta XIX Congress on International Ornithology (1986), Vol II. University of Ottawa Press, Ottawa, p 1740-1758

Finney SK, Wanless S, Harris MP (1999) The effect of weather conditions on the feeding behaviour of a diving bird, the common guillemot, Uria aalge. J Avian Biol 30:23-30

Flint P, Fowler AC (1998) A drift experiment to assess the influence of wind on recovery or oiled seabirds on St Paul Island, Alaska. Mar Pollut Bull 36:165-166
Forney KA, Benson SR, Cameron GA (2001) Central California gillnet effort and bycatch of sensitive species, 1990-1998. In: Melvin EF, Parrish JK (eds) Seabird bycatch: trends, roadblocks, and solutions. AK-SG-01-01, University of Alaska Sea Grant, Anchorage, AK, p 141-160

Furness RW, Greenwood JJD (1993) Birds as monitors of environmental change. Chapman \& Hall, London

Furness RW, Camphuysen KCJ (1997) Seabirds as monitors of the marine environment. ICES J Mar Sci 54:726-737

Gaston AJ, Dechesne SBC (1996) Rhinoceros auklet (Cerorhinca monocerata). In: Poole A, Gill F (eds) The birds of North America, No. 212. The Academy of Natural Sciences, Philadelphia, PA, and The American Ornithologists' Union, Washington, DC

Gleason KL (2006) United States. In: Shein KA (ed) State of the climate in 2005. Bull Am Meteorol Soc 87:62-66

Granadeiro JP, Silva MA (1993) Beached bird surveys in Portugal 1991-92 and relationship between weather and density of corpses. Sula 7:1-8

Granadeiro JP, Silva MA, Fernandes C, Reis A (1997) Beached bird surveys in Portugal 1990-1996. Ardeola 44:9-17

Hass T, Parrish JK (2002) Beached birds: a COASST field guide. Wavefall Press, Seattle, WA

Hickey BM (1989) Patterns and processes of shelf and slope circulation. In: Landry MR, Hickey BM (eds) Coastal oceanography of Washington and Oregon. Elsevier Science, Amsterdam, p 41-115

Hickey BM, Banas NS (2003) Oceanography of the US Pacific Northwest coastal ocean and estuaries with application to coastal ecology. Estuaries 26:1010-1031

Huyer A (1983) Coastal upwelling in the California Current System. Prog Oceanogr 12:259-284

Kistler R (2001) The NCEP-NCAR 50-year reanalysis: monthly means CD-ROM and documentation. Bull Am Meteorol Soc 82:247-267

Kosro PM, Peterson WT, Hickey BM, Shearman RK, Pierce SD (2006) Physical versus biological spring transition: 2005. Geophys Res Lett 33:L22S03

MacFadyen A, Hickey BM, Foreman MCG (2005) Transport of surface waters from the Juan de Fuca eddy region to the Washington coast. Cont Shelf Res 25:2008-2021

Mackas DL, Peterson WT, Ohman MD, Lavaniegos BE (2006) Zooplankton anomalies in the California Current system before and during the warm ocean conditions of 2005 . Geophys Res Lett 33:L22S07

Manuwal DA, Thoresen AC (1993) Cassin's auklet (Ptychoramphus aleuticus). In: Poole A, Gill F (eds) The birds of North America, No. 50. The Academy of Natural Sciences, Philadelphia, PA, and The American Ornithologists' Union, Washington, DC

Mueter FJ, Ware DM, Peterman RM (2002) Spatial correlation patterns in coastal environmental variables and survival rates of Pacific salmon in the Northeast Pacific Ocean. Fish Oceanogr 11:205-218

Newton I (2006) Can conditions experienced during migration limit the population levels of birds? J Ornithol 147: 146-166

Norris JR (2000) Interannual and interdecadal variability in the storm track, cloudiness and sea surface temperature over the summertime North Pacific. J Clim 13:422-430

Peterson WT, Keister JE (2003) Interannual variability in copepod community composition at a coastal station in the northern California Current: a multivariate approach. Deep-Sea Res II 50:2499-2517

Roemmich D, McGowan J (1995) Climatic warming and the decline of zooplankton in the California Current. Science 267:1324-1326 
Scholin CA, Gulland F, Douchette GJ, Benson S and others (2000) Mortality of sea lions along the Central California coast linked to a toxic diatom bloom. Nature 403:80-84

Schreiber EA (2002) Climate and weather effects on seabirds. In: Schreiber EA, Burger J (eds) Biology of marine birds. CRC Press, New York, p 179-215

Schwing FB, O'Farrell M, Steger JM, Baltz K (1996) Coastal upwelling indices, west coast of North America, 1946-1995. NOAA Tech Mem NOAA 231:1-32

Schwing FB, Bond NA, Bograd SJ, Mitchell T, Alexander MA, Mantua N (2006) Delayed coastal upwelling along the U.S. west coast in 2005: a historical perspective. Geophys Res Lett 33:L22S01

Strub PT, Allen JS, Huyer A, Smith RL (1987) Large-scale structure of the spring transition in the coastal ocean off western North America. J Geophys Res C 92:1527-1544

Sydeman WJ, Bradley RW, Warzybok P, Abraham CL and others (2006) Planktivorous auklet Ptychoramphus aleuticus responses to the anomaly of 2005 in the California Current. Geophys Res Lett 33:L22S09

Editorial responsibility: Howard Browman (Associate Editorin-Chief), Storebø, Norway
Veit RR, Pyle P, McGowan JA (1996) Ocean warming and long-term change in pelagic bird abundance within the California current system. Mar Ecol Prog Ser 139:11-18

Wallace EAH, Wallace GE (1998) Brandt's cormorant (Phalacrocorax penicillatus). In: Poole A, Gill F (eds) The birds of North America, No. 362. The Birds of North America, Philadelphia, PA

Wiese FK, Robertson GJ (2004) Assesing seabird mortality from chronic oil discharges at sea. J Wildl Manag 68: $627-638$

Wiese FK (2003) Sinking rates of dead birds: improving estimates of seabird mortality due to oiling. Mar Ornithol 31: $65-70$

Wiese FK, Ryan PC (2003) The extent of chronic marine oil pollution in southeastern Newfoundland waters assessed through beached bird surveys 1984-1999. Mar Pollut Bull 46:1090-1101

Wilson UW (1991) Response of three seabird species to El Niño events and other warm water episodes on the Washington coast, 1979-1990. Condor 93:853-858

Submitted: November 7, 2006; Accepted: October 14, 2007 Proofs received from author(s): November 13, 2007 